\title{
Wandering and Ecological Ethos in 'A hora e vez de Augusto Matraga'
}

\author{
REX NIELSON \\ Brigham Young University
}

\begin{abstract}
João Guimarães Rosa locates nearly all his fiction in the Brazilian sertão, the vast, semi-arid backlands of Brazil's interior, yet surprisingly few studies exist regarding Guimarães Rosa's environmental attitudes or the ecological ethos present in his work. Pressing environmental concerns in Brazil have nevertheless inspired new readings of Guimarães Rosa's work that consider the ecological consciousness latent in his fiction. Guimarães Rosa's well-known novella, "A hora e vez de Augusto Matraga," reveals a powerful ecological ethos by modeling the concept of wandering - a way of relating to nature and to others. The story demonstrates that acquiring aesthetic sensitivity and developing ecological understanding occur simultaneously, and they work together to establish social and communal harmony.
\end{abstract}

Keywords: Ecocriticism; João Guimarães Rosa; nature; sertão; wandering; community

"And when I wander here and there I then do most go right."

(Shakespeare IV.3)

Few Brazilian writers are more closely identified with the sertão than João Guimarães Rosa. Guimarães Rosa locates nearly all his fiction in the Brazilian sertão, the vast, semi-arid backlands of Brazil's interior, yet surprisingly few studies exist regarding Guimarães Rosa's environmental attitudes or the 
ecological ethos present in his work. One reason for this stems in part from the history of literary criticism regarding Guimarães Rosa's writings. When Sagarana, his first major work, was published in 1946, initial reviews identified it as merely the latest manifestation of a tradition of regionalist writing in Brazilian letters, in this case, a collection of stories about the regionlandscape, people and customs - of the sertão in Minas Gerais. Against this initial reductionist reading, numerous critics subsequently saw in Sagarana and Guimarães Rosa's later works much more than mere regional fiction. As Luiz Valente aptly summarizes: “'A hora e vez de Augusto Matraga' tem como cenário o sertão, que, como sabemos, não significa na obra rosiana apenas uma localização geográfica, mas também uma dimensão mítica onde o drama da existência humana pode ser levado até as últimas consequências" (102). Today the sertão as a mythic and even universalized space remains at the core of most readings of Guimarães Rosa's fiction. One may consider, for example, Antonio Candido's classic formulation: “A província do sr. Guimarães Rosa, no caso Minas, é menos uma região do Brasil do que uma região da arte" (185). Candido further asserts that "Sagarana não é um livro regional" (185), and elsewhere he famously calls Sagarana an example of a type of "superRegionalismo" (87). Beginning with Candido, critics have employed an assortment of terms to name the complex, mythic, timeless, and even placeless qualities of Guimarães Rosa's fiction. These have included "neo-regionalismo," "regionalismo transcendental," "regionalismo universal," "transrealismo," and others. Guimarães Rosa's own acute interest in esoteric and philosophical issues has encouraged this critical tendency, which tends to distance his work from physical reality - from nature as it were. This gesture is inherently ironic, given the way nature pervades Guimarães Rosa's fiction from Sagarana to his last published stories. One consequence of this critical positioning is the fact that scholars of Guimarães Rosa have tended to approach the sertão as an abstraction, as a space outside of time and place. Critics almost universally read the sertão metaphorically, symbolically, mythically, and even allegorically, without adequately considering the real geographies Guimarães Rosa describes or the ecological consciousness expressed in his fiction.

Global anxieties over human relations with nature have in recent years brought new critical attention to the ways in which literary texts engage with the environment. In fact, the surge in scholarship focused on literary 
representations of nature has even given rise to a disciplinary subfield of literary studies - ecocriticism - that has its own professional organizations, scholarly conferences, and academic journals. ${ }^{1}$ Pressing environmental concerns in Brazil have similarly inspired new readings of Guimarães Rosa's work that take into serious account the ecological consciousness latent in his fiction.

An exceptional example of such an ecocritical approach is the interdisciplinary work of Mônica Meyer, a biologist and educator who forcefully argues in favor of reading the sertão not as scenery but rather as a rich and complex narrative component: "A narrative é construída de modo que a realidade humana se entrelace com o mundo natural de tal forma que a identidade de cada um seja o resultado de uma relação de reciprocidade. $\mathrm{Na}$ obra rosiana a natureza se faz sempre presente" (25). She notes further that "a natureza do homem e a natureza dos outros elementos que compõem o mundo natural se entrelaçam e as mudanças vão se processando simultaneamente" (26). ${ }^{2}$ The interconnectedness Meyer's work highlights between human experience and the natural world also resonates strongly with another recent development within ecological thought that is best summarized by Eduardo Viveiros de Castro's notion of "multinaturalism".3 Multinaturalism, or "perspectivism," as it is sometimes called, invites us to think of ourselves as "always inhabiting a multiplicity of intersecting spatialities and realities" (Hage 8). Such an approach presumes an ecological consciousness of infinite interconnected modes of being in the world.

David Abram has described a similar ecological awareness manifested among indigenous shamans of southeast Asia: "The shaman or sorcerer is the

\footnotetext{
${ }^{1}$ Consider, for example, the Association for the Study of Literature and Environment (ASLE), an organization founded in 1992 by "a group of scholars and writers interested in exploring the meanings of the natural environment and the complexities of human relationships with each other, and with the more-than-human world, and to deepening the impact of these explorations both within and beyond the classroom" (ASLE, "Vision and History"). The association now boasts an active membership of 1450 and sponsors a quarterly peer-reviewed journal. Evidence of the expanding reach of ecocritical studies within Luso-Brazilian literature can be found in the increase in the number of panels addressing ecocritical topics at conferences such as BRASA, APSA, and LASA, along with special numbers devoted to ecocriticism in scholarly journals.

${ }^{2}$ For another example of ecocritical scholarship, see McNee. This study focuses on contemporary artists and poets; however, it intelligently models ecocritical approaches to literary texts.

${ }^{3}$ For a complete discussion of the terms "multinaturalism" and "perspectivism," see Viveiros de Castro.
} 
exemplary voyager in the intermediate realm between the human and the morethan-human worlds, the primary strategist and negotiator in any dealings with the Others" (7). In his work, Abram describes the "journeys" of shamans as a manner of relating to nature, to the nonhuman world. ${ }^{4}$ Abram characterizes these "journeys" less as physical expeditions following specific routes and more as a way of entering an "intermediate realm between the human and the more-than-human" (7). In a manner that predates but resonates strongly with the formulations of Viveiros de Castro and Abram, Guimarães Rosa's wellknown novella, "A hora e vez de Augusto Matraga," reveals a powerful ecological ethos by modeling a particular form of "journeying" or wandering into nature and relating with the Other. The story demonstrates that acquiring aesthetic sensitivity and developing ecological understanding occur simultaneously, de mãos dadas, and work together to establish social and communal harmony.

Writers throughout the Americas have long valued the power of poetry to create relationships with place and community. Wallace Stegner has argued, for example, that a place is not a place until it has a poet. ${ }^{5}$ Derek Walcott similarly argues that poetry seeks fresh metaphor through an idiosyncratic experience with landscapes, thereby allowing us to connect our identity to certain locations. ${ }^{6}$ Edouard Glissant likewise finds inspiration in the unique flora and fauna of the Caribbean, which serve as the genesis for new ways of identifying place and establishing community. In the Poetics of Relation, for example, Glissant praises the rhizome - a root system common to various species of plants in his home island country of Martinique - as a principle for metaphor:

\footnotetext{
${ }^{4}$ David Abram describes shamans as figures who mediate "between the human community and the larger community of [...] nonhuman entities that constitute the local landscape, from the diverse plants and the myriad animals - birds, mammals, fish, reptiles, insects - that inhabit or migrate through the region, to the particular winds and weather patterns that inform the local geography, as well as the various landforms - forests, rivers, caves, mountains - that lend their specific character to the surrounding earth" (7).

5 Stegner writes: "No place is a place until things that have happened in it are remembered in history, ballads, yarns, legends, or monuments" (203). He later argues: "No place is a place until it has had a poet. [...] No place, not even a wild place, is place until it has had that human attention that at its highest reach we call poetry. What Frost did for New Hampshire and Vermont, what Faulkner did for Mississippi and Steinbeck for the Salinas Valley, Wendell Berry is doing for his family corner of Kentucky" (205). Along these lines, Paulo Moreira eloquently argues for a comparative reading of William Faulkner, Juan Rulfo, and João Guimarães Rosa due to their commitment to specific locales.

${ }^{6}$ See, for example, Walcott.
} 
The rhizome [is] an enmeshed root system, a network spreading either in the ground or in the air [that] maintains the idea of rootedness but challenges that of a totalitarian root. Rhizomatic thought is the principle behind what I call the Poetics of Relation, in which each and every identity is extended through a relationship with the Other. (11)

Glissant's notion of rhizomatic thinking, coupled with his valuation of errantry and wandering, illuminates Guimarães Rosa's fiction and in particular "A hora e a vez de Augusto Matraga." In this story, he presents a model for social relationships as well as human relation with the natural environment that begins in wandering, in what Glissant would call rhizomatic thought, in letting go of autocratic and egocentric modes of self-identification. "A hora e vez de Augusto Matraga" optimistically reveals the effects of reconciling oneself to one's history, land, and community through a process of wandering that Abram might describe as "propelling [one's] awareness laterally, outward into the depths of a landscape at once both sensuous and pscychological" (10). The story suggests that one may escape the isolation and intolerance of a totalitarian form of identity and develop a respectful "relationship with the Other" through a grounded sense of place and identity conditioned by aesthetic sensitivity and ecological awareness.

The story's relatively simple plot centers on Augusto Matraga, a stereotypical strong man, powerful yet cruel, a man of substantial lands and influence who is feared rather than respected by nearly all around him. He alternates between ignoring and abusing his wife and young daughter, as well as everyone else with whom he associates. Consequently, and within the opening pages of the story, his wife takes their daughter and flees with another man. Augusto is subsequently betrayed by his own hired ruffians, who have been conscripted by a local rival who seeks to replace Augusto as the supreme authority in town. The guns for hire murder Augusto's only loyal servant and then ambush Augusto himself - they beat him, callously brand him with a cattle iron, and finally leave him for dead. He miraculously escapes by throwing himself into a deep and craggy ravine to evade certain death at the hands of his rival's men. In hiding, Augusto is saved and nursed back to health by two aging freed slaves, who happen to live near the bottom of the ravine. It is during this 
period of physical recovery that Augusto undergoes a spiritual awakening, and upon regaining his strength, he departs along with his aged benefactors to find some remote place where he can escape his violent past and begin a new life. After many years of solitary work caring for the old couple he has come to love, Augusto realizes that to complete his atonement he must come to terms with his past by returning to reconcile himself with society.

Three distinct phases characterize the novella, or rather the life of Augusto Matraga. In the first phase, Augusto exhibits an insular self-centeredness typical of autocrats. The second period is one of remorse, during which Augusto removes himself from society and seeks repentance through solitary labor. The third phase presents Augusto's ability finally to recognize the Other, which brings him back into relation with the land and his community. Guimarães Rosa situates these themes of repentance and redemption in the sertão, but as in the case of the other stories in Sagarana, the sertão functions not just as a setting but itself as the Other that Augusto must learn to respect and comprehend. Until Augusto Matraga learns to acknowledge, see, and respect the natural world that surrounds him, he cannot fully acknowledge, see and respect the members of his community.

Augusto's trajectory through the story's cycle parallels Glissant's notion of errantry: "uprooting can work toward identity, and exile can be seen as beneficial, when these are experienced as a search for the Other" (18). Glissant continues, "One who is errant (who is no longer traveler, discoverer, or conqueror) strives to know the totality of the world yet already knows he will never accomplish this - and knows that is precisely where the threatened beauty of the world resides" (20). Augusto is forcibly uprooted from his community, but on the advice of the local priest, he voluntarily chooses exile in order to do penance for his crimes against his family, community, and land. Augusto intends to work in solitude for the rest of his life as a sort of monastic penance, and during this process of exile, he learns to wander, "no longer traveler, discoverer, or conqueror." As a wanderer, Augusto unexpectedly (from his point of view) discovers the Other of the sertão, and through his wandering, Augusto develops a sense of respect and awe before the power of nature, simultaneously developing a sense of place and identity. Whereas a rooted form of totalitarian egocentrism characterized his initial sense of identity-he saw himself as the law and refused to acknowledge or respect any identity or Law 
other than his own - through his errantry or wandering, he develops a more honest and open relationship with the land. This newfound sense of place in turn leads him back into relation with his community. The moment of his return to society signifies the fulfillment of his newfound sense of identity-his "hora" and his "vez."

At the beginning of the story, the narrator describes a devastating setting of drought. The sun scorches the land, drying up any moisture, leaving the earth parched and arid. In such conditions, wind and the accompanying dust storms become very dangerous. Guimarães Rosa uses dust throughout the novella to typify Augusto's relationship to the land. Augusto initially inherits extensive tracts of land, yet he relates to this land abstractly and solely in terms of ownership and possession. He does not view himself as a steward; rather, he sees the land only as territory - an extension of his power and authority. His relationship to both land and people is totalitarian, and he refuses to acknowledge any other kind of relationship to the land. The decline of his land's productivity eventually signals the fall of his empire: "dívidas enormes," "falta de crédito," "terras no demando," and "as fazendas escritas por pago" (369). He has squandered his inheritance and proven himself an unworthy steward. His fallen state becomes literal when his former hired men betray him: "empurraram-no para o chão, e ele nem se moveu" (375). They literally bring him down to earth.

The earth itself betrays Augusto when he initially seeks retribution. After he discovers that his men have left, Augusto rides after them to try and prevent their complete desertion. As he rides, the wind picks up and "cresceu a poeira, de peneira" (373); dust envelops him like a shroud of fog. The earth yawns to consume him. Nevertheless, Augusto hardens his defiant and even frenzied determination to assert his will and sense of identity regardless of his current situation. When he discovers the departure of his wife and daughter, he wildly swears to kill the man with whom they left, and when he discovers that all of his servants but one have abandoned him to serve a local rival, he swears he will track them down and force their obedience. His sense of identity stem from a single root and so must exclude, even to the point of violence, any other claim to legitimacy. Augusto, however, discovers that his own claims have been frustrated. Betrayed by his wife and servants, Augusto finds himself isolated 
and powerless to exert any form of control. Even the dust of the earth revolts against his authority.

Standing alone, Augusto confronts his rival and former men, ordering them to return to the plantation. The wind carries away his orders, however, and instead of obeying him, his men beat him until he lies at their feet almost dead. His rival then orders him to be taken into the jungle and killed. At the point when he is about to be murdered, he musters a final burst of strength and escapes by throwing himself into a nearby ravine. The ravine is treacherous, and his pursuers, unwilling to risk the descent, assume he has died. Amazingly, at the bottom of the ravine, Augusto survives but lies broken and bloody in the dust, which has become muddy by mingling with his blood: "meio nu, todo picado de faca, quebrado de pancadas e enlameado grosso, poeira com sangue" (375). For the first time in his life, Augusto finds himself the victim of totalitarian violence.

This moment constitutes what Glissant might call a violent act of uprooting. Augusto is abandoned by his community and severed from his rooted sense of identity. In the same act, moreover, he is forced for the first time to confront the Other on its own terms. He has no ability to exert control or assert his identity. At this moment, the narrator solemnly declares that Augusto has disappeared into another world: "E era como se tivesse caído num fundo de abismo, em outro mundo distante" (378). Augusto has literally fallen out of the world of power. This passage also resonates strongly with Glissant's descriptions of the ocean's abyss and the terrors of slavery during the middle passage:

Your chasms are our own unconscious, furrowed with fugitive memories [...]. Experience of the abyss lies inside and outside the abyss. The torment of those who never escaped it: straight from the belly of the slave ship into the violet belly of the ocean depths they went. But their ordeal did not die; it quickened into this continuous/discontinuous thing: the panic of the new land, the haunting of the former land, finally the alliance with the imposed land, suffered and redeemed. The unconscious memory of the abyss served as the alluvium for these metamorphoses. (7) 
In "A hora e vez de Augusto Matraga," the sertão functions in a way strikingly similar to the abyss of the ocean in Glissant's writing. Like the ocean, Guimarães Rosa's sertão also acts as a chasm, as a repository for the stories and histories of individuals who have suffered violence. Until this moment in the story, Augusto has never acknowledged the stories and histories of others, most notably the stories of those closest to him: he has never truly communicated with his wife and daughter or his one faithful servant. Thrown into the abyss, however, Augusto will begin to understand, "from the inside," the pain of being excluded, ignored, invalidated, and forgotten. The abyss of the sertão thus serves as an "alluvium for [Augusto's] metamorphosis." Just as Glissant's abyss holds the remnants, wreckage, and memory of the middle passage, Guimarães Rosa's chasm similarly is inhabited by former slaves who have been forgotten and marginalized in Brazilian society.

Another important metaphor also emerges from this moment of the novella: "Mas Nhô Augusto era couro ainda por curtir" (373). Guimarães Rosa draws upon the legacy of slavery and the relationship between master and slave by calling him "Nhô Augusto," a clear reference to the form by which a slave would address a master. Furthermore, this passage evokes the imagery of the sertão and the culture of leather. Augusto previously owned many head of cattle, but the narrator notes that it is the owner, not his cattle, who needs to be cured. This image foreshadows the refining process that Augusto has yet to endure, but the metaphor has curious and specific allusions. Leather is cured by being stretched, beaten, and weathered, suggesting that Augusto must also be stretched, beaten, weathered, and humbled. The first phase of the story, characterized by Augusto's insular self-centeredness and inability to relate to the Other, thus ends with the image of Augusto lying alone in a deep abyss in dust and his own blood.

Lying at the bottom of the ravine, literally abandoned by his former men and figuratively abandoned by society, Augusto is saved by an aged couple, two former slaves, who live in a humble shack hidden and out of sight. Significantly, this man and woman also represent a history characterized by race-based discrimination and violence that has been forgotten and excluded by the totalitarianism of the center. Hidden in the margins of society, this couple lives in the sertão's abyss: what Glissant refers to as the alluvium of History's forgotten histories. Ironically, Augusto is saved by encountering the remnants 
of a culture he previously marginalized and, possibly, even violently excluded (the narrator implies Augusto's mistreatment of blacks in the opening pages of the novella). The couple discover Augusto and take him into their home, where they begin to care for him. The old woman initially fears that the ruffians who drove him into the ravine will return, but her fears are allayed when her husband notes that deeper in the ravine a stray calf has died and a flock of vultures now circle overhead. If the rufffians were to return, the vultures would cause them to believe that Augusto has died. Rich in religious imagery, the vultures signal the death of Augusto's former identity, and the calf represents an offering for Augusto's former life and the possibility of redemption. The scene evokes the opening line of the novella, "Matraga não é Matraga" (363), and the metamorphosis that Augusto Matraga will undergo.

As Augusto recovers physically in the couple's home, he finds himself spiritually depressed over the loss of his former life. He loses hope and feels he has no reason to live, for he cannot as yet imagine his identity rooted in anything but a totalitarian model. Augusto initially feels regret and nostalgia rather than contrition, and he yearns for a previous state of innocence - the time of his childhood. In his early years, his mother wanted him to join the clergy and made him memorize numerous prayers and passages of scripture. As Augusto recovers, he remembers the prayers he learned as a child, and he begins to think about the idea of absolution and the possibility of redemption.

To help him find forgiveness, the old couple travels to town under the cover of night and returns with a priest who is willing to speak with Augusto. The priest gives Augusto hope that he can repent, saying that he must give himself up to God and perform penance. Augusto responds by saying, "Fé eu tenho, fé eu peço, Padre" (379), evoking the Roman centurion of the New Testament who confessed, "Lord, I believe; help though mine unbelief" (Mark 9:24). Guimarães Rosa reveals here a significant element of the process of penance according to Roman Catholic doctrine. For Catholics, repentance lies in two debts one incures through sin and transgression: culpa and poena. Whereas Protestantism emphasizes the importance of acknowledging God's grace as the essential saving attribute, Catholicism also lays significant responsibility on the shoulders of the sinner. Culpa literally means "guilt" and can only be forgiven by God, through His grace. God will forgive the sinner if the sinner humbly demonstrates sincere contrition. But the sinner also incurs 
poena, which is literally punishment and represents the penance that the sinner must pass through in order to receive forgiveness. In Guimarães Rosa's sense of redemption, penance must be paid-Augusto must labor in order to receive grace. Indeed, Guimarães Rosa seems to suggest that Augusto must pass through the via crucis of Catholic doctrine. ${ }^{7}$

The priest observes that Augusto, who inherited his lands and property, has never labored, and he instructs him to work as though he were three men and to help others as often as possible: "Você nunca trabalhou, não é? Pois, agora, por diante, cada dia de Deus você deve trabalhar por três, e ajudar os outros, sempre que puder" (379-80). He then continues, "Reze e trabalhe, fazendo de conta que esta vida é um dia de capina com sol quente, que às vezes custa muito a passar, mas sempre passa. E você ainda pode ter muito pedaço bom de alegria. Cada um tem a sua hora e a sua vez: você há de ter a sua" (380). The priest ends his counsel with the promise of a proverb: "Everyone has his hour and his turn; and yours will come." The priest then counsels Augusto to leave the place where he is currently living and seek out a place where he can work and serve others. Augusto sees that his former life and identity have ended. He also believes that he will never be "gente," or a member of society, again, and so he dedicates his life to penance and resigns himself to wander in exile. The priest specifically counsels Augusto to undertake the labor of "capina," hoeing and working the land. The priest advises him to cultivate the land, work in the garden, and take care of his benefactors and anyone else he can. The ethic of Guimarães Rosa's story begins to emerge-Augusto will establish a new and open sense of identity by working the land.

The day after the priest's visit, Augusto and the old couple leave the small shack at the bottom of the ravine and go in search of a new life. This departure marks the beginning of Augusto's errantry. On the road, just as they prepare to leave, Augusto kneels with his arms spread in the form of a crucifix. He then swears, "Eu vou p'ra o céu, e vou mesmo, por bem ou por mal! [...] E a minha vez há de chegar [...]. P'ra o céu eu vou, nem que seja a porrete!” (381). One might read this ambiguous passage as a revelation of the residual elements of Augusto's initial authoritarianism, as he insists that he will go to heaven, even

${ }^{7}$ The via crucis, or "Way of the Cross," refers to the road Christ took as he carried the cross to Golgatha. In Catholic theology, the via crucis is a devotional exercise, a means by which one can approach God, adore Him, and increase understanding and love for Him. 
if by the force of violence. ${ }^{8}$ However, the passage may also be read as an exclamation of determination, that Augusto will go to heaven despite the beating he may endure. In this sense, the passage evokes the via crucis. Like all professed Christians, Augusto must endure the road of tribulation on his way to salvation. Kneeling in the dust, Augusto finds himself close to the land, and the scene recalls the earlier episode in which he was beaten, forced to the ground, and seemingly swallowed by the land. The difference in attitude, though, is dramatic. Whereas in the prior scene his defiance and pride were violently quelched, he now kneels humbly. The land both takes and gives life, and it can effect both Augusto's death and rebirth.

Many critics have noted that Guimarães Rosa presents the sertão as a theater for exploring the polarities of life and death, good and evil, love and hate, existence and non-being. Earl Fitz argues that the sertão "functions symbolically like Melville's whale, presenting human existence as an [...] interweaving of good and evil, a tangled web of events, motivations, and interpretations" (186). In a passage from Guimarães Rosa's Grande sertão: veredas, the narrator explains the possibility for both life and death in the sertão:

Melhor, se arrepare: pois, num chão, e com igual formato de ramos e folhas, não dá a mandioca mansa, que se come comum, e a mandioca-brava, que mata? Agora, o senhor já viu uma estranhez? A mandioca-doce pode de repente virar azangadamotivos não sei. [...] E, ora veja: a outra, a mandioca-brava, também é que às vezes pode ficar mansa, a esmo, de se comer sem nenhum mal. (11-12)

In a similar way, Augusto has been changed from bitter to sweet, or as Marilyn Robinson notes in an essay about the deserts of the western United States, "It has happened over and over again that promised land or holy land by one reckoning is wasteland by another" (248). The land's potential to be "promised land" or "wasteland" is determined by the nature of the individual's relations to the land, by the individual's sense of place. As Augusto wanders out into the

\footnotetext{
${ }^{8}$ I thank my colleague Marília Librandi for this insight. See also Ribeiro.
} 
sertão and begins to work, his relationship to it changes. He no longer sees the land as territory, a space of legal authority, a space to be conquered. Despite this change, his relation to the land initially remains undefined. Though determined to follow the priest's advice to work and cultivate the land, he does not yet know exactly what that entails. Departing from his elderly benefactors, Augusto opens himself to the possibility of redemption.

Augusto and the old couple wander deep into the sertão until they come to a tiny village called Tombador, literally "a tumbling, steep hillside." The village's name references the difficult path Augusto must follow as well as the place from which he has come. When the wanderers arrive in the town, the villagers view Augusto as a curious man; he seems too foreign to be understood and they cannot comprehend his motives and work ethic. He resigns himself to a solitary labor and accordingly separates himself from the world and society. The travelers build a hut and Augusto begins to work, clearing the land, digging ditches, and cultivating a garden. He works harder than any other individual in the town: "Trabalhava que nem um afadigado por dinheiro, mas, no feito, não tinha nenhuma ganância e nem se importava com acrescentes. [...] E só pedia, pois, serviço para fazer, e pouca ou nenhuma conversa" (382). Augusto's actions contrast starkly with his previous behavior and reveal that he has truly renounced his former sense of identity. He works not to accumulate wealth or to extend his authority or territory. He reveals that he is truly severed from his former self.

Augusto follows the priest's counsel precisely; however, his new life of solitary and selfless labor does not bring the spiritual relief he desires. Despite his claims to help only others ("o que vivia era querendo ajudar aos outros" (383)), Augusto emotionally and spiritually separates himself from those around him. He develops no relationship with his aging benefactors. True, he cares for them, but he does not communicate with them. They exist merely as the instrument of his service. Similarly, he develops no true relationship with anyone in the town: "só pedia, pois, serviço para fazer, e pouca ou nenhuma conversa" (382). Despite relinquishing a sense of identity based on autocratic and totalitarian principles, he nonetheless remains isolated because he has not yet learned to recognize others. His fierce determination to work out his salvation continues to prevent him from acknowledging the Other. In a similar manner, Augusto fails at this point to develop any meaningful relation to the 
land, which now exists for Augusto only in an objectified manner as something for Augusto to work on. Though he works hard and spends countless hours on the land and among his neighbors, he lives an ascetic life of isolation: "Quase sempre estava conversando sozinho, e isso também era de maluco, diziam; porque eles ignoravam que o que fazia era apenas repetir a fala final do padre: 'Cada um tem a sua hora e a sua vez: você há-de ter a sua.' E era só” (383). Having isolated and immersed himself in work, Augusto tries to escape from his past. This position of isolation, however, ironically inhibits him from becoming reconciled with the past and fully repenting, that is, from developing a feeling of wholeness.

A series of events, including a crucial experience with the natural world, ultimately lead Augusto out of his self-imposed isolation. The first occurs when one of Augusto's distant relatives happens to pass through the village and recognizes him. The relative recounts to Augusto how Quim Recadeiro, his only loyal servant, was brutally murdered around the time Augusto disappeared. He further informs him that his wife is now living with the man with whom she left and is even considering remarrying. He also adds that, sadly, Augusto's daughter was seduced by a traveling salesman and has not been seen or heard from since. This information weighs heavily upon Augusto, who has worked for so many years to forget his former life and gain a new sense of identity. Augusto pleads with his relative not to tell anyone of his existence, explaining that the former Augusto is dead: "Matraga não é Matraga" (363). The relative responds contemptuously to this: "Estou vendo, mesmo. Estou vendo" (384). The derision of this response profoundly shakes Augusto. As hard as he has tried to escape from his former life, he cannot. As deep as he has wandered into the sertão, he cannot escape his own complicity in the history he wishes to escape. Augusto leaves his relative and runs into a nearby grove of banana trees and begins to pray for mercy. He cannot shake his feeling of hopelessness and falls into a sense of regret and sorrow for his earlier life: "Mas o mais terrível era que o desmazelo de alma em que se achava não the deixava esperança nenhuma do jeito de que o Céu podia ser" (385).

Augusto's spiritual progress is inhibited in two ways. First, he has isolated himself from society. While attempting to gain a new sense of identity by laboring to atone for his failed relationships with wife, daughter, and society, he has not developed new relationships from which a new sense of identity may be 
established. Second, he has unsuccessfully attempted to escape his history rather than seeking to reconcile himself to it. Rather than truly wandering in the sertão in the open manner defined by Glissant, Augusto has sought merely to escape his former life. His preoccupation with the past has become a form of nostalgia for some irrecoverable moment of innocence, and the fact that he lost that innocence consumes him. Speaking generally about nostalgia, John Elder observes that "nostalgia, like other forms of sentimentality, can be an isolating fantasy, a barrier between us and the true objects of our desire" (16). In a similar way, Augusto's regret over his past acts as a barrier that prevents him from attaining the true object of his desire - to feel whole and be redeemed.

Another person arrives in Tombador, however, who serves to draw Augusto out from under the smothering weight of isolation and nostalgia he feels. The man is a famous and feared outlaw named Joãozinho Bem Bem. While on his way to meet some fellow bandits, he too happens upon the small village. As the village cowers in fear, Augusto recognizes in Joãozinho many of his own traits, and surprisingly, Joãozinho and Augusto immediately become friends. Augusto invites Joãozinho and his men to his humble home, and he makes every effort to serve them a fine dinner and be otherwise solicitous. Before leaving the following day, Joãozinho invites Augusto to join him. This invitation is a singular temptation that threatens to carry Augusto back to his former life and identity rooted in violence and totalitarianism. Augusto succesfully resists the temptation and declines, but the experience depresses him. As he considers Joãozinho's fame and authority throughout the land, he realizes that although he has removed himself from his society and despite his years of penance and labor, his former identity must surely live on in infamy. Despite the fact that he abandoned society, his reputation lives on as an autocrat, a violent and self-centered strongman.

A crucial and intriguing development occurs in Augusto's life shortly after the departure of Joãozinho Bem Bem. Augusto again rededicates himself to his labors. He is bent on working harder than ever, yet as he toils, hoeing and working the land, his focus shifts little by little from the abstract concept of labor to the object of his labor, that is, from the idea of penance to the actual landscape he inhabits. His senses awaken as he begins to see the life that surrounds him: 
Mas, afinal, as chuvas cessaram, e deu uma manhã em que Nhô Augusto saiu para o terreiro e desconheceu o mundo: um sol, talqualzinho a bola de enxofre do fundo do pote, marinhava céu acima, num azul de água sem praias, com luz jogada de um para o outro lado, e um desperdício de verdes cá embaixo - a manhã mais bonita que ele já pudera ver.

Estava capinando, na beira do rego.

De repente, na aultura, a manhã gargalhou: um bando de maitacas passava, tinindo guizos, partindo vidros, estralejando de rir. E outro. Mais outro. E ainda outro, mais baixo, comas maitacas verdinhas, grulhantes, gralhantes, incapazes de acertarem as vozes na disciplina de uma coro.

Depois, um grupo verde-azulado, mais sóbrio de gritos e em fileiras mais juntas.

—Uai! Até as maracanãs!

$[\ldots]$

- Virgem! Estão todas assanhadas, pensando que já tem milho nas roças... Mas, também, comoé que podia haver um demanhã mesmo bonito, sem as maitacas?!...

O sol ia subindo, por cima do vôo das aves itinerantes. Do outro lado da cerca, passou uma rapariga. Bonita! Todas as mulheres eram bonitas. Todo anjo do céu devia de ser mulher.

E Nhô Augusto pegou a cantar a cantiga, muito velha, do capiau exilado:

'Eu quero ver a moreninha tabaroa, arregaçada, enchendo o pote na lagoa...' (399-400)

This awakening through song continues, expanding to the physical world around him: "Cantar, só, não fazia mal, não era pecado. As estradas cantavam. E ele achava muitas coisas bonitas, e tudo era mesmo bonito, como são todas as coisas, nos caminhos do sertão" (401). Finally, something in Augusto shifts in a decisive way: "Pela primeira vez na sua vida, se extasiou com as pinturas do poente, com os três coqueiros subindo da linha da montanha para se recortarem num fundo alaranjado, onde, na descida do sol, muitas nuvens pegam fogo" (402). After long years of labor, Augusto begins to see the land for the first 
time. He first notices the sun and the sky, then frogs, tree toads, scorpions, and worms. He observes birds, parrots, and toucans of all shapes, colors, and varieties. The light plays with the shadows, the clouds seem bigger. He notices plants: ancient rosewood trees and thick underlying brush. Finally, he sees a young woman who passes nearby, and he notes her beauty and the beauty of all women. His senses bring him back to his own corporality and for the first time in many years he becomes conscious of sensation in his body. Life pulses through him anew: "A força da vida nele latejava, em ondas largas, numa tensão confortante, que era um regresso e um ressurgimento" (398). Following numerous years of solitary work in the land, Augusto finally has learned to see, and as he sees the world around him, observing the wonders of the sertão as though for the first time, his only response is to stand silently in awe.

Against the subsequent dramatic events that conclude the novella, this scene constitutes a pivotal moment in the story. Augusto initially viewed the land only as territory, the extension of his authority and an abstract representation of his political strength. He likewise viewed people in the same materialist form as property. Even during his search for absolution, he remained disconnected from those around him and isolated from the land, which he viewed as merely the object of his labors. Only when he learns to see the land not as a construction, or as an abstract projection of territory, does he develop the capacity to see the Other. The narrator notes, "Nhô Augusto saiu para o terreiro e desconheceu o mundo" (399). The word choice of this passage typifies Guimarães Rosa's at times recondite style by emphasizing Augusto's abrupt unfamiliarity with the world. He sees the world not according to his former perspective but in a manner such that the world presents itself as entirely Other. This change in posture and point of view does not imply that Augusto now comprehends the totality of the sertão but rather the fact that Augusto is developing a stance of openness before the sertão, and this sense of respect leads him to a new form of self-identity. The land awakens in him an aesthetic sensitivity and this in turn changes his moral and ethical outlook. Guimarães Rosa reveals here a somewhat romantic view of landscape and nature by establishing a powerful link between the aesthetic and the ethical, and 
this relationship in turn serves as the basis for a new ecological view of and relation with the land. ${ }^{9}$

As Augusto begins to sense the implications of his newfound sense of identity and relation to the world, his thoughts turn to his family and community. He suddenly realizes that he can no longer remain hidden in the sertão; he feels the need to reestablish his relationship with his family and society. He wishes to apologize and acknowledge his past transgressions, but more than anything, he wants to re-engage with the world, to enter into a relationship of honest communication with all around him. Accordingly, Augusto bids farewell to the village and his benefactors and begins the journey home. Significantly, his return trajectory does follow a straight line back to a point of origin. He does not run or flee, nor does his movement carry the predetermined purpose and authority of someone on a mission. Instead, he saddles his humble donkey and leaves to wander into the sertão. With this departure, however, Augusto's wandering is not imbued with the guilt and shame (or the culpa and poena) that characterized his first departure. By wandering, Augusto sees and relates to the world in an entirely new manner: "E também, nas encruzilhadas, ele deixava que o bandito asno escolhesse o caminho, bulindo com as conhcas dos ouvidos e ornejando. E bastava batesse no campo o pio de uma perdiz magoada, ou viesse do mato a lália lamúria dos tucanos, para o jumento mudra de rota, pendendo à esquerda ou se empescoçando para a direita" (404). Without imposing direction or order on the animal, Augusto proceeds through the sertão, admiring the beauty of a world previously unknown to him.

The narrative's well-known climax, Augusto's "hora e vez," arrives suddenly. While making his way home, Augusto enters an obscure village and is surprised to discover that Joãozinho Bem-Bem has taken control of it. Joãozinho welcomes Augusto, but Augusto's arrival coincides with that of a humble farmer who kneels before Joãozinho to plead for the life of his son, whom Joãozinho has condemned to death. Joãozinho is determined to punish the young man for having killed one of Joãozinho's men, albeit in self-defense. The entire town watches helplessly as Joãozinho exercises his control and

\footnotetext{
${ }^{9}$ I wish to express thanks to Malcolm McNee for suggesting this connection between Guimarães Rosa's work and Romantic philosophy. For an alternate reading of the sertão as Romantic symbol, see Tosta.
} 
dominion over the village. Without ceremony Augusto calmly tells Joãozinho that he will not allow the young man to be killed. He implores clemency, but Joãozinho's temper flares at this challenge to his authority, a clear mirror of Augusto's behavior from the opening of the novella. Each man hesitates briefly before reaching for the nearest gun. When the smoke settles, both men are found to be mortally wounded. The village rushes to thank the stranger who has saved them, and among the crowd Augusto recognizes a cousin:

—E hein, hein João?

-P'ra ver...

-Põe a benção na minha filha [...] seja lá onde for que ela esteja [...]. Fala com a Dionóra que está tudo em ordem! (413)

In a complete reversal from the beginning of the novel, Augusto finds himself challenging, rather than defensively guarding, the totalitarianism of Joãozinho Bem-Bem. His motive stems from the respect he now feels for all life. His newfound sense of identity derives from his relationship to the land as well as to his community, and he feels the need to preserve and stand up for that relationship at all costs. Appropriately, with his dying words to his cousin, Augusto redeems his former identity. He no longer seeks to escape from his past relationships or even to restore those relationships to the way they were; he instead makes peace with his wife and accepts her as she now is.

Notwithstanding its dramatic conclusion, "A hora e vez de Augusto Matraga" offers a powerful ethos regarding the sertão and the relation between humans and nature. Though Augusto Matraga is initially caught up in the violent egocentrism inherent in a totalitarian worldview, he ultimately finds redemption by learning to wander, to see the natural world around him, and to love others through an open, respectful and authentic relationship. This love is both instigated and conditioned by an aesthetic relationship to nature. The sertão teaches Augusto respect, and as he learns to stand in awe of the beauty that surrounds him, he begins to see beyond himself, to recognize the Other. This seeing beyond not only allows him to "get outside" of himself, to develop a relationship with the land and with others, but ultimately it allows himself to see himself, to love himself. 
"A hora e vez de Augusto Matraga" answers Glissant's call for "founding works $[\ldots]$ that $[\ldots]$ use a similar dialectics of rerouting, asserting, for example, political strength but, simultaneously, the rhizome of a multiple relationship with the Other and basing every community's reasons for existence on a modern form of the sacred, which would be, all in all, a Poetics of Relation" (16). Critics have tended to focus on the final shoot-out between Augusto Matraga and Joãozinho Bem-Bem and the conflicting symbolic systems of order and civilization these characters represent; however, by giving consideration to the presence of the natural world in the story, one begins to see a key aspect of Guimarães Rosa's aesthetic project. "A hora e vez de Augusto Matraga" presents Augusto's relation to the sertão as a modern form of the sacred, a wandering in the world, that promotes not only an aesthetic relation with nature, but one with formidable social and political implications, as well. In this, Guimarães Rosa demonstrates the possibility for a reconciliation between humans and nature, between humans and community, and ultimately between humans and their own rhizomatic selves.

\section{Works Cited}

Association for the Study of Literature and Environment. "Vision and History," www.asle.org/discover-asle/vision-history/. Accessed 2 Nov. 2016.

Candido, Antonio. Literatura e Sociedade. Nacional, 1965.

Elder, John. Reading the Mountains of Home. Harvard UP, 1998.

Fitz, Earl. Rediscovering the New World: Inter-American Literature in a Comparative Context. U of Iowa P, 1991.

Glissant, Édouard. Poetics of Relation, translated by Betsy Wing. U of Michigan P, 2000.

Hage, Ghassan. "Dwelling in the Reality of Utopian Thought." Traditional Dwellings and Settlements Review, vol. 23, no.1, 2016, pp. 7-13.

McNee, Malcolm. The Environmental Imaginary in Brazilian Poetry and Art. Palgrave Macmillan, 2014.

Meyer, Mônica. Ser-tão Natureza: A natureza em Guimarães Rosa. U Federal de Minas Gerais, 2008.

Moreira, Paulo. Modernismo Localista das Américas: Os contos de Faulkner, Guimarães Rosa e Rulfo. U Federal de Minas Gerais, 2012. 
Ribeiro, Renato Janine. “Augusto Matraga, a salvação pelo porrete.” Personae: grandes personagens da literatura brasileira, edited by Lourenço Dantas Mota and Benjamin Abdala Junior, Editora SENAC, 2001, pp. 195-208.

Robinson, Marilyn. "Wilderness." Death of Adam: Essays on Modern Thought, Houghton Mifflin, 1998, p. 245-54.

Rosa, João Guimarães. Grande sertão: veredas. José Olympio, 1979.

—. Sagarana. Universal, 2001.

Shakespeare, William. The Winter's Tale, edited by Stephen Orgel, Oxford UP, 1998.

Stegner, Wallace. "The Sense of Place." Where the Bluebird Sings to the Lemonade Springs: Living and Writing in the West. Random House, 1992.

Tosta, Antônio Luciano de Andrade. "O 'sublime' sertão em O sertanejo, Os sertões e Grande sertão: veredas." Letras de Hoje, vol. 36, no. 1, 2001, pp. 7-26.

Valente, Luiz Fernando. "Variations on the Kenotic Hero: Tolstoy's Ivan Ilych and Guimarães Rosa's Augusto Matraga.” Symposium, vol. 45, no. 2, 1991, pp. 126-39.

Viveiros de Castro, Eduardo. A inconstância da alma selvagem. Cosac Naify, 2002.

Walcott, Derek. "Isla Incognita." Caribbean Literature and the Environment: Between Nature and Culture, edited by Elizabeth M. DeLoughrey, Renée K. Gosson, and George B. Handley, U of Virginia P, 2005, pp. 51-57. 